\title{
COMPILATION OF MOLECULAR DATA FOR THE PHYLOGENY OF THE GENUS AUSTROPOTAMOBIUS: ONE SPECIES OR SEVERAL?
}

\author{
F. GRANDJEAN, M. FRELON-RAIMOND, C. SOUTY-GROSSET
}

Laboratoire de Génétique et Biologie des Populations de Crustacés, UMR CNRS 6556, Université de Poitiers, 40 Avenue du recteur Pineau, F-86022 POITIERS cedex, France. E-mail : Frederic.Grandjean@univ-poitiers.fr

\begin{abstract}
The phylogenetic relationships of the genus Austropotamobius were reviewed by the compilation of two recent genetic studies based on the partial nucleotide sequence of the mitochondrial RNA $16 \mathrm{~S}$ gene. The results showed a well-resolved phylogeny revealing four distinct clades: $A 1, A 2, A 3$ and $B$, supported by high bootstrap values. The clades $A$ (including $A 1, A 2, A 3$ ) and $B$ are separated by a high genetic divergence (5\%). In accordance with morphological and nuclear data, two species could be defined: $A$. italicus and $A$. pallipes, respectively. The average of genetic divergence within the major group $A$ and $B$ was $2.1 \% \pm 1.2$ and $0.9 \% \pm 0.6$ respectively. Three clades $A 1, A 2$ and $A 3$ correspond mainly to crayfish sampled from Austria-Switzerland, South of Balkans and Italy-Spain respectively. On the basis of morphological, genetic and distribution data, a new systematic - based on two species $A$. pallipes and $A$. italicus with 3 subspecies A. i. carinthiacus, A. i. carsicus and A. i. italicus - could be proposed for the white-clawed crayfish species complex. We rejected the specific status of $A$. berndhauseri and A. $i$. Iusitanicus given to the Swiss and Spanish crayfish respectively.
\end{abstract}

Key-words : Austropotamobius, species complex, phylogeny, 16S RNA.

\section{COMPILATION DE DONNÉES MOLÉCULAIRES POUR RÉSOUDRE LA PHYLOGÉNIE DU GENRE AUSTROPOTAMOBIUS : UNE OU PLUSIEURS ESPĖCES?}

\section{RÉSUMÉ}

Les relations phylogénétiques du genre Austropotamobius ont été revues en compilant deux récentes études génétiques basées sur la séquence nucléotidique partielle du gène mitochondrial codant pour la grande sous-unité de l'ARN ribosomal 16S. Les résultats ont montré une phylogénie robuste révélant quatre groupes: $A 1, A 2, A 3$ et $B$, supportés par de fortes valeurs de bootstrap. Les groupes $A$ et $B$ sont séparés par une forte distance génétique (5\%). En accord avec les données morphologiques et nucléaires, deux espèces peuvent être définies : A. pallipes et $A$. italicus. La moyenne de divergence génétique à l'intérieur des groupes $A$ et $B$ est respectivement de 2,1 \% $\pm 1,2$ et $0,9 \% \pm 0,6$. Les trois groupes A1, A2 et A3 correspondent principalement aux écrevisses échantillonnées en Autriche-Suisse, au Sud des Balkans et en Italie-Espagne 
respectivement. Sur la base des données morphologiques, génétiques et géographiques, une nouvelle systématique - basée sur l'existence de deux espèces $A$. pallipes et $A$. italicus et trois sous-espèces $A$. $i$. carinthiacus, $A$. $i$. carsicus et $A$. $i$. italicus - peut être proposée chez le complexe d'espèces de l'écrevisse à pattes blanches. Nous rejetons les statuts taxonomiques spécifiques, $A$. berndhauseri, et $A$. $i$. lusitanicus donnés aux écrevisses suisses et espagnoles.

Mots-clés : Austropotamobius, complexe d'espèces, phylogénie, ARN 16S.

\section{INTRODUCTION}

Although all authors agree on specific status for the stone crayfish A. torrentium (BOTT, 1950; KARAMAN, 1963; ALBRECHT, 1982, 1983), the systematics of the whiteclawed crayfish species complex remains controversial. Thus the systematics of the genus Austropotamobius is a matter of continuing debate, especially because morphological data provide ambiguous phylogenetic evidence. Several distinct classifications have been proposed by different systematists: some proposing one species and multiple subspecies or varieties while others recommend numerous species. The most significant taxonomic studies, based mainly on morphological criteria, are compiled in Table I:

(1) BOTT $(1950,1972)$ recognized two species: A. berndhauseri restricted to Southern Switzerland, more precisely in canton Tessin and southern valleys of the canton of Graübuden, and $A$. pallipes in western Europe (Table I). For A. pallipes, he described three sub-species: A. p. pallipes in Great Britain, Ireland, France, Switzerland and Corsica; italicus in Italy, Dalmatia and Switzerland and lusitanicus in the Iberian Peninsula. According to this author, italicus and lusitanicus differ from pallipes by the shape of the rostrum and its basal spines, while italicus and lusitanicus are separated by the presence of hairs on the upper border of the endopod of the second male gonopod in lusitanicus. However, such characters are of limited value for identifying specimens because they differ considerably from one population to another and the differences between sub-species are small. FROGLIA (1978) reported specimens in northern Piemonte and Liguria that had characters intermediate between pallipes and italicus. ALMACA (1987) and GRANDJEAN et al. (1998) found that most male lusitanicus specimens had no hairs on the second gonopod. LÖRSTCHER et al. (1997) reported specimen having intermediate morphological characters between A. p. pallipes and A. berndhauseri.

(2) KARAMAN (1963) named two species, A. pallipes and $A$. italicus, subdividing the latter into three subspecies $A$. i. italicus, $A$. i. lusitanicus and $A$. $i$. carsicus, with the last one distributed in the former Yugoslavia.

(3) ALBRECHT (1982) reported one species, A. pallipes, with several varieties in France, Spain, and Italy.

(4) STAROBOGATOV (1995) recognized 4 species with six sub-species (see Table I).

Where morphological data are inconclusive, genetic characters may provide accurate and unambiguous indicators of taxonomic divergence (WILSON et al., 1985). The analysis of genetic structure of populations has recently led to the development of a new species concept that CRACRAFT (1983) called the Phylogenetic Species Concept (PSC). Based on the study of the genealogical relationship between taxa, the status of a taxon is related to its genetic uniqueness and whether or not it is monophyletic. However, the threshold for any taxonomic level is somewhat subjective. For this reason, AVISE and BALL (1990) recommend that morphological, biological and phylogenetic data be considered together to make a clear decision on the specific status of a group. At the intraspecific level, this method could be used for the definiton of subspecies, when associated with the spatial distribution of lineages (AVISE et al., 1987). 
Table I

List of references to taxonomic studies of the Austropotamobius pallipes complex species.

Tableau I

Liste de références des études taxonomiques du complexe d'espèces Austropotamobius pallipes.

\begin{tabular}{|c|c|c|c|c|c|}
\hline Authors & Genus & Species & Subspecies & Distribution & Data \\
\hline BOTT $(1950,1972)$ & Austropotamobius & $\begin{array}{l}\text { pallipes } \\
\text { berndhauseri }\end{array}$ & $\begin{array}{l}\text { pallipes } \\
\text { italicus } \\
\text { lusitanicus }\end{array}$ & $\begin{array}{l}\text { France-British Isles } \\
\text { Italy, Balkans } \\
\text { Spain } \\
\text { Switzerland }\end{array}$ & Morphology \\
\hline KARAMAN (1963) & Austropotamobius & $\begin{array}{l}\text { pallipes } \\
\text { italicus }\end{array}$ & $\begin{array}{l}\text { italicus } \\
\text { lusitanicus } \\
\text { carsicus } \\
\end{array}$ & $\begin{array}{l}\text { France-British Isles } \\
\text { Italy } \\
\text { Spain } \\
\text { Balkans } \\
\end{array}$ & Morphology \\
\hline ALBRECHT (1982) & Austropotamobius & pallipes & $\begin{array}{l}\text { pallipes } \\
\text { lombardicus } \\
\text { carinthiacus } \\
\text { trentinicus }\end{array}$ & $\begin{array}{l}\text { France } \\
\text { Northern Italy } \\
\text { Austria } \\
\text { trentin }\end{array}$ & Morphology \\
\hline BRODSKY (1983) & Austropotamobius & $\begin{array}{l}\text { pallipes } \\
\text { italicus }\end{array}$ & $\begin{array}{l}\text { pallipes } \\
\text { bispinosus } \\
\text { italicus } \\
\text { lusitanicus } \\
\text { carsicus }\end{array}$ & $\begin{array}{l}\text { France-British Isles } \\
\text { Italy } \\
\text { Italy } \\
\text { Spain } \\
\text { Balkans }\end{array}$ & $\begin{array}{l}\text { Morphology } \\
\text { Biogeography }\end{array}$ \\
\hline PRETZMANN (1987) & Austropotamobius & $\begin{array}{l}\text { pallipes } \\
\text { pallipes }\end{array}$ & $\begin{array}{l}\text { pallipes } \\
\text { fulcisianus = italicus }\end{array}$ & $\begin{array}{l}\text { France-British Isles-Spain-portugal-Switzerland } \\
\text { North of Italy, Apennins, Dalamatia }\end{array}$ & $\begin{array}{l}\text { Morphology } \\
\text { Biogeography }\end{array}$ \\
\hline STAROBORATOV (1995) & Atlantoastacus & $\begin{array}{l}\text { pallipes } \\
\text { fulsinacus } \\
\text { orientalis } \\
\text { lusitanicus }\end{array}$ & $\begin{array}{l}\text { pallipes } \\
\text { rhodanicus } \\
\text { fulsinacus }=\text { A. benrdhauseri }+ \\
\text { A. } p . \text { lombardicus }+ \text { A. } p . \text { trentinicus } \\
\text { italicus } \\
\text { orientalis = carsicus } \\
\text { carinthiacus }\end{array}$ & $\begin{array}{l}\text { France-British Isles } \\
\text { Switzerland-Trentin } \\
\text { Italy } \\
\text { Austria } \\
\text { Balkans } \\
\text { Spain }\end{array}$ & Morphology \\
\hline GRANDJEAN et al. (1998) & Austropotamobius & pallipes & $\begin{array}{l}\text { pallipes } \\
\text { italicus } \\
\text { lusitanicus }\end{array}$ & $\begin{array}{l}\text { France-British Isles } \\
\text { Balkans } \\
\text { Spain }\end{array}$ & $\begin{array}{l}\text { mt DNA by RFLP } \\
\text { Morphology }\end{array}$ \\
\hline GRANDJEAN et al. (2000) & Austropotamobius & $\begin{array}{l}\text { pallipes } \\
\text { italicus } \\
\text { benrdhauseri? }\end{array}$ & $\begin{array}{l}\text { pallipes } \\
\text { italicus } \\
\text { carsicus } \\
\text { carinthiacus }\end{array}$ & $\begin{array}{l}\text { France-England-Ireland } \\
\text { Italy-Spain } \\
\text { Balkans } \\
\text { Switzerland-Austria } \\
\text { Not sampled }\end{array}$ & mt 16S rDNA \\
\hline
\end{tabular}


In Astacidae and particularly in the white-clawed crayfish species complex, most recent molecular studies (Table II) have focused on the genetic structure of populations with no taxonomic inference (SANTUCCl et al., 1997; LÖRSTCHER et al., 1997; SOUTY-GROSSETet al., 1997; GRANDJEAN et al., 1997a, b, 2001; GRANDJEAN and SOUTY-GROSSET, 2000a, b; GOUIN et al., 2001). ALBRECHT (1982) used allozyme electrophoresis to evaluate taxonomic issues within Astacidae, but the absence of polymorphism detected by this technique limited the informativeness of this study. Recently, SANTUCCl et al. (1997) and LÖRSTCHER et al. (1997) have revealed the efficiency of allozymes to study the genetic structure of Italian and Swiss populations respectively. Mitochondrial DNA (mtDNA) is a widely used marker for studying population differentiation because of its maternal, non-recombining mode of inheritance and rapid rate of evolution. Phylogeographic studies have shown that most species have hierarchical and sometimes deep genetic structures (AVISE, 1994) and specially in freshwater vertebrates (TSIGENOPOULOS and BERREBI, 2000). Recently, GRANDJEAN et al. (1998) reported the existence of three genetic entities among four European populations based on the analysis of total mitochondrial DNA by restriction fragment length polymorphism (RFLP) corresponding to the three subspecies described by BOTT (1950). But their results are of limited taxonomic values due to the restricted sampling area including only few samples from France, England, Spain and Slovenia.

More recently, based on the analysis of mitochondrial gene for the 16S RNA, an opinion has been expressed that the traditional morphology-based taxonomy is inconsistent with the white-clawed crayfish molecular phylogeny (GRANDJEAN et al., 2000). They recommended that a taxonomic classification based on molecular phylogeny should be accepted. However, their study did not include a sample from Switzerland where A. berndhauseri (BOTT, 1972) or A. fulcisianus (STAROBOGATOV, 1995) occurs. However, LARGIADÈR et al. (2000) published a similar study on Swiss populations. These two works gave the opportunity to re-examine the taxonomy of $A$. pallipes species complex over its range by the compilation of the whole of 16S RNA sequences. The phylogeny obtained is discussed with the light of recent nuclear genetic and morphological studies.

Table II

List of references on genetic studies conducted on the Austropotamobius pallipes species complex.

Tableau II

Liste de références des études génétiques sur le complexe d'espèces Austropotamobius pallipes.

\begin{tabular}{|c|c|c|c|c|}
\hline Authors & & Sampling location & Population Number & Markers \\
\hline \multirow[t]{4}{*}{ GRANDJEAN et al. } & $1997 a$ & England & 4 & MtDNA RFLP \\
\hline & $1997 b$ & Spain-Slovenia-France-England & 5 & \\
\hline & 1998 & Spain-Slovenia-France-England & 4 & \\
\hline & 2001 & Spain & 14 & \\
\hline \multirow[t]{2}{*}{ GRANDJEAN and SOUTY-GROSSET } & $2000 a$ & France & 10 & \\
\hline & $2000 b$ & France & 25 & \\
\hline SANTUCCI et al. & 1997 & Italy & 31 & Allozyme \\
\hline LÖRSTCHER et al. & 1997 & Swiss-Italy & 19 & \\
\hline LARGIARDÈR et al. & 2000 & Swiss-Italy & 25 & \\
\hline SOUTY-GROSSET et al. & 1999 & France & 9 & RAPDs \\
\hline GOUIN et al. & 2001 & France-Bristish Isles & 15 & \\
\hline
\end{tabular}




\section{MATERIAL AND METHODS}

Sampling - We examined 29 partial 16S rRNA sequences obtained from two studies performed by GRANDJEAN et al. (2000) and LARGIADĖR et al. (2000). The sequences have been deposited in GenBank under accession numbers AF237590-AF237610 (without AF237598: this sequence is very short compared to the others, with few unresolved sites) and AJ242700-AJ242711, in GRANDJEAN et al. (2000) and LARGIADÈR et al. (2000), respectively. The sequence (AF237599) corresponding to an individual of $A$. torrentium has been chosen as an outgroup. The sampling covers the entire range of white-clawed crayfish with animals coming from Austria, Great Britain, France, Ireland, Italy, Slovenia, Spain and Switzerland.

Alignment and phylogenetic inferences - Partial 16S rRNA sequences from Austropotamobius pallipes were manually aligned with the sequence of Austropotamobius torrentium (AF237599) as an outgroup. The phylogenetic analysis was performed on the resulting data matrix of 18 sequences ( 11 sequences were not included in this analysis due to redundancy of samples from the two previous studies) and 467 sites. Gaps were treated as missing data.

In phylogenetic estimation, it is necessary to justify a model of evolution used to model character-state changes (HUELSENBECK and CRANDALL, 1997). We used the program ModelTest (POSADA and CRANDALL, 1998) to test alternative models of evolution for our data using likelihood ratio tests. The program tests a number of null hypotheses, including: (1) equal base frequencies, (2) equal transition/transversion rates, (3) equal rates within transition and transversion classes, (4) equal rates of substitution and (5) no invariable sites. We tested all these hypotheses in order to optimize a model of evolution. Phylogenetic trees were inferred using PAUP 4.0b8a software (SWOFFORD, 1998). Tree reconstructions were performed using maximum likelihood and distance methods assuming the substitution model selected by ModelTest and rate heterogeneity across sites. The likelihood search was performed using random sequence addition and setting parameters to values indicated in the model optimisation. The search was heuristic based on branch swapping by tree bisection-reconnection (TBR). Computation of distances was done using the neighbour joining algorithm (SAITOU and NEI, 1987). Bootstrap analysis was performed with 1000 pseudoreplicates (FELSENSTEIN, 1985).

\section{RESULTS}

Within the data matrix of 18 sequences, we rejected the null hypothesis of equal base frequencies. There appears to be an AT bias in these data (base frequencies: $A=0.3383, C=0.1161, G=0.2103$ and $T=0.3353$ ). The transition/transversion ratio was 2.3463. The model of substitution selected by hierarchical likelihood ratio tests was therefore the HKY85 model (HASEGAWA et al., 1985) with a gamma distribution shape parameter estimated to 0.672 . Figure 1 shows the tree inferred from ML analysis (In likelihood value of -1162.69). Irrespective of the two methods employed (distance or ML), all phylogenetic inferences exhibited identical topology.

The phylogenetic analyses support the separation of the four clades (labelled A1 including mainly individuals from Italian, Spanish and French specimens, A2 including mainly individuals from Austrian and Swiss ones and A3 including mainly individuals from Slovenian and B including individuals from England, France, Corsica and Ireland). All clades are supported by high bootstrap values (Figure 1).

The average of genetic divergence within the major group A (including A1, A2 and A3) and clade $B$ were $2.1 \% \pm 1.2$ and $0.9 \% \pm 0.6$, respectively (Table III). The average between the major group $A$ and the clade $B$ was $5.0 \pm 1 \%$. Range of different taxa are illustrated in Figure 2. 


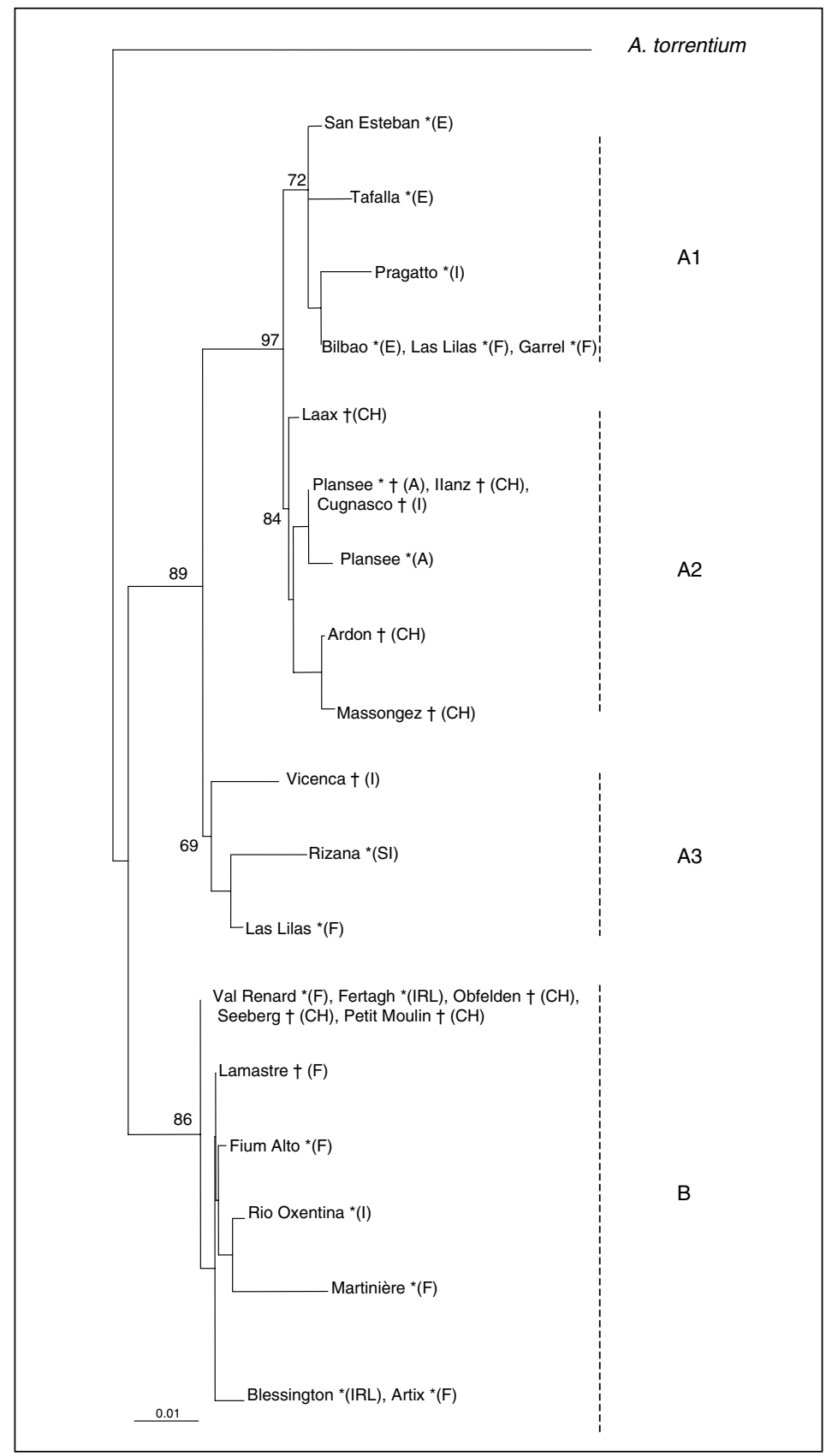

Figure 1

Maximum likelihood tree derived from analysis based on mt 16S rDNA characters using the HKY85 model (HASEGAWA et al., 1985) from PAUP (4.0b8a version: SWOFFORD, 1998) rooted using $A$. torrentium. Numbers at nodes indicate boostrap support $\geq 60 \%$ (1 000 replicates). Populations labelled $\dagger$ or ${ }^{*}$ are issued from LARGIADER et al. (2000) and GRANDJEAN et al. (2000) respectively. The clades labelled A1, A2 and A3 correspond to the subspecies of $A$. italicus: $A$. $i$. italicus, $A$. $i$. carinthiacus and $A$. $i$. carsicus, respectively and the clade $B$ to $A$. pallipes.

Figure 1

Arbre obtenu par la méthode du maximum de vraisemblance à partir des séquences mitochondriales de l'ADNr 16S sous le modèle HKY 85 (HASEGAWA et al., 1985) dans PAUP 4.0b8a version : SWOFFORD, 1998) raciné par $A$. torrentium. Les valeurs de bootstrap ( $\geq 60 \%$ ) sont indiquées au niveau des nœuds (1 000 réplicats). Les populations marquées $\dagger$ et * sont issues de LARGIADĖR et al. (2000) et GRANDJEAN et al. (2000) respectivement. Les groupes $\mathrm{A} 1, \mathrm{~A} 2$ et $\mathrm{A} 3$ correspondent aux sous-espèces d'A. italicus : A. i. italicus, $A$. $i$. carinthiacus et $A$. $i$. carsicus, et le groupe B à $A$. pallipes. 
Table III

Pairwise genetic divergence mean within and among species or subspecies.

Tableau III

Divergence génétique moyenne inter et intra taxons.

\begin{tabular}{lcccc}
\cline { 2 - 5 } & $\begin{array}{c}\text { Clade A1 } \\
(\text { A. i. italicus })\end{array}$ & $\begin{array}{c}\text { Clade A2 } \\
(\text { A. i. carinthiacus })\end{array}$ & $\begin{array}{c}\text { Clade A3 } \\
(\text { A. i. carsicus })\end{array}$ & $\begin{array}{c}\text { Clade B } \\
(\text { A. pallipes })\end{array}$ \\
\hline Clade A1 & $0.009 \pm 0.005$ & $0.014 \pm 0.005$ & $0.036 \pm 0.007$ & $0.054 \pm 0.009$ \\
Clade A2 & & $0.007 \pm 0.004$ & $0.030 \pm 0.006$ & $0.051 \pm 0.008$ \\
Clade A3 & & & $0.019 \pm 0.005$ & $0.043 \pm 0.01$ \\
Clade B & & & & $0.009 \pm 0.006$ \\
\hline
\end{tabular}

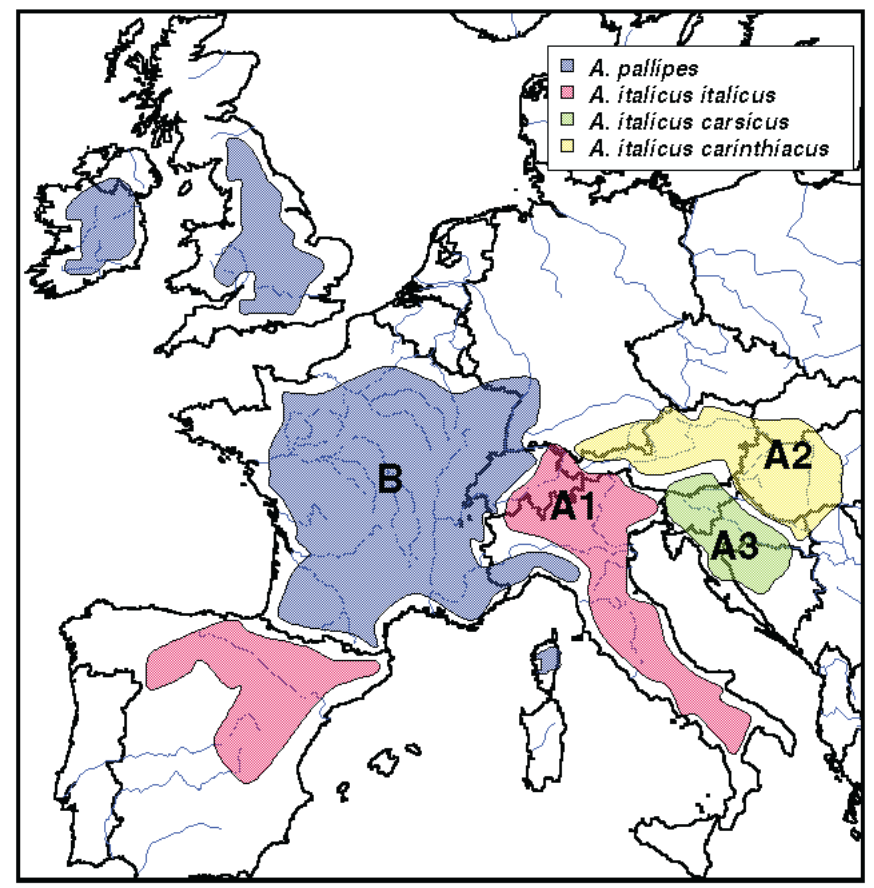

Figure 2

Range of taxa described in the white-crayfish species complex.

\section{Figure 2}

Aire de distribution des taxons décrits au sein du complexe d'espèces d'écrevisse à pattes blanches.

\section{DISCUSSION}

The results of this study reveal a well-resolved phylogeny. Maximum likelihood analysis identified two major reciprocal monophyletic groups of mtDNA sequence in the A. pallipes species complex (Clades $A$ and $B$ ). Haplotypes from clade $A$ are found in crayfish from France, Ireland and North of Italy and those of type $B$ have been characterized from crayfish distributed in Switzerland, Austria, Italy, Balkans and Spain. These groups are strongly supported by the highest bootstrap percentages. Furthermore, they show high levels of genetic divergence on average $5 \%$ with a range of 4.3 to $5.4 \%$. These two clades correspond perfectly with those previously reported Type A and B 
described by GRANDJEAN et al. (2000). This is supported by other data sets such as nuclear markers and morphology. Indeed, in recent studies on allozymes, SANTUCCI et al. (1997), LÖRSTCHER et al. (1997) and LARGIARDÈR et al. (2000) also revealed a strong genetic structure among populations located in France and England and those sampled in Italy, Slovenia and Switzerland. SANTUCCI et al. (1997) reported an average Nei's genetic distance between these two clades of 0.30 (range $0.26-0.40$ ). Moreover, they revealed a lack of $\mathrm{F} 1$ hybrids in sympatric areas which demonstrates their reproductive isolation in the field. Morphological results also are concordant with genetic data from mitochondrial and nuclear markers. LAURENT and SUSCILLON (1962) and GRANDJEAN et al. (1998) reported a $A / R$ ratio (apex to rostrum length ratio) of approximately 0.22 for populations sampled in France and England, while populations from Balkans, Italy and Spain had ratios greater than 0.29. Similarly, the number of spines behind the cervical groove also allowed the discrimination of two geographically separated clades (LAURENT and SUSCILLON, 1962; ALBRECHT, 1982; GRANDJEAN et al., 1998). Individuals from clade A had a number of spines significantly higher (mean 2.8) than those from clade B (mean 1). All these results showed that these two clades appear to constitute separate lineages with a long history of independent evolution. According to AVISE and BALL (1990), concordant divergence among clades for two or more unlinked markers could be candidates for species that we recognized as being $A$. italicus and $A$. pallipes for the clades $A$ and $B$ respectively.

Within the major group $A$, three well resolved clusters $A 1, A 2$ and $A 3$ are defined with high bootstrap values $(\geq 69 \%)$. These clades correspond to those found by GRANDJEAN et al. (2000). No additional branch occurs, waiting for the addition of a new species ( $A$. berndhauseri included in the study of LARGIADĖR et al. (2000)) in the phylogenetic analysis. The $A$. berndhauseri specimens are clustered with Austrian ones into clade A2. This result is in accordance with the geographical closeness of these populations. In their studies, LARGIADĖR et al. (2000) showed that populations of crayfish from Clade 2 are widespread in Southern Switzerland. Moreover A2 is genetically closer related to A1 including haplotypes from Italian-Spanish crayfishes than the clade A3 harbouring haplotypes from Slovenian ones. Thus this phylogenetic analysis does not confirm the specific status of $A$. berndhauseri given by BOTT (1972) to Swiss crayfish. The Austrian populations of crayfish have been morphologically studied by MACHINO (1997). This author confirmed the variety carinthiacus described by ALBRECHT (1982) from Austrian crayfish. According to these data, clade 2 could correspond to $A$. italicus carinthiacus. This phylogeny also lies with the placement of $A$. italicus lusitanicus specimen described as being endemic from Spain. Haplotypes from Spanish specimens are similar with those found in Italian samples. Recent population studies based on genetics and/or morphology are congruent with our data. GRANDJEAN et al. (2000) and SANTUCCI et al. (1997) revealed an absence of genetic differentiation between Spanish and Italian specimens from both mtDNA 16S RNA and allozyme markers. In a recent study to survey the extent and the pattern of genetic variation across the Spanish range of this species, GRANDJEAN et al. (2001) found one haplotype from the 154 animals sampled from 14 Spanish populations. This haplotype was also recorded in Italian populations, which populations showed a high intrapopulational variability. In agreement with the close genetic relationship based on both genetic markers, the authors assumed a translocation of crayfish from Italy to Spain and avoided the traditionally accepted subspecific status recognized for Spanish specimens. These results were concordant with morphological data (ALMACA, 1987; GRANDJEAN et al., 1998). This example clarifies the taxonomic confusion existing within this species-complex before the application of genetic markers.

No intra-subdivisions were supported within clade B. A. pallipes seems to be the unique taxon. In the light of molecular studies, including samples covering the entire ranges of the $A$. pallipes species complex, a new systematics can be proposed for the whiteclawed crayfish species complex based on two species $A$. pallipes and $A$. italicus with 3 subspecies A. i. carinthiacus, A. i. carsicus and A. i. italicus. 


\section{ACKNOWLEDGEMENTS}

We thank J.D. Reynolds and one anonymous reviewer for constructive comments on an earlier version of this paper.

\section{REFERENCES}

ALBRECHT H., 1982. Das system der europäischen flusskrebse (Decapoda, Astacidae) : vorschlag und begrundung. Mitteilungen aus dem Hamburgischen Zoologischen Museum Institut, 79, 187-210.

ALBRECHT H., 1983. Besiedlungsgeschichte und ursprünglich holozane verbreitung der europäischen Flusskrebse. Spixiana, 6, 61-77.

ALMACA C., 1987. On the Portuguese populations of Austropotamobius pallipes (Lereboullet, 1858). Investigacion Pesquera, 51, 403-411.

AVISE J.C., 1994. Molecular markers, natural history and evolution. Chapman and Hall. New York, $511 \mathrm{p}$.

AVISE J.C., BALL R.M., 1990. Principles of genealogical concordance in species concepts and biological taxonomy. In : FUTUYAMA D. and ANTONOVICS J. (Eds.), Oxford Surveys in Evolutionary Biology, Vol. 7, 45-67. Oxford University Press, New York.

AVISE J.C., ARNOLD J., BALL R.M., BERMINGHAM E., LAMB T., NEIGEL J.E., 1987. Intraspecific phylogeography: the mitochondrial DNA bridge between population genetics and systematics. Annual Review Ecology and Systematics, 18, 489-522.

BOTT R., 1950. Die Flusskrebse europas (Decapoda, Astacidae). Proceedings of the Senckenberg Naturalist Society, 483, 1-36.

BOTT R., 1972. Besiedlungsgeschichte and systematic des Astacieden West-Europas unter besonderer beruchksichtigung der schweiz. Revue Suisse de Zoologie, 79, 387-408.

BRODSKY S.Y., 1983. On the systematics of palaearctic crayfishes (Crustacea, Astacidae). Freshwater Crayfish, 5, 464-470.

CRACRAFT J., 1983. Species concepts and speciation analysis. Current Ornithology, 1, 59-187.

FELSENSTEIN J., 1985. Confidence limits on phylogenies: an approach using the bootstrap. Evolution, 39, 783-791.

FROGLIA C., 1978. Decapodi (Crustacea Decapoda). In : RUFFO S. (ed.), Guide per il riconoscimento delle specie animali delle acque interne italiane, $A Q / 1 / 9 / 4$, Consiglio Nazionale delle Richerche, Verona, Italy, $39 \mathrm{p}$.

GOUIN N., GRANDJEAN F., BOUCHON D., REYNOLDS J.D., SOUTY-GROSSET C., 2001. Population genetic structure of the endangered freshwater crayfish Austropotamobius pallipes, assessed using RAPD markers. Heredity, 87, 80-87.

GRANDJEAN F., SOUTY-GROSSET C., 2000a. Genetic and morphological variation in the endangered crayfish species, Austropotamobius pallipes (Lereboullet) (Crustacea, Astacidae) from the Poitou-Charentes region (France). Aquatic Science, 62, 1-19.

GRANDJEAN F., SOUTY-GROSSET C., 2000b. Mitochondrial DNA variation and population genetic structure of the white-clawed crayfish, Austropotamobius pallipes. Conservation Genetics, 1, 309-319.

GRANDJEAN F., SOUTY-GROSSET C., HOLDICH D.M., 1997a. Mitochondrial DNA variation in four British populations of the white-clawed crayfish Austropotamobius pallipes pallipes: implications for the management. Aquatic Living Resources, 10, 121-126.

GRANDJEAN F., SOUTY-GROSSET C., RAIMOND R., HOLDICH D.M., 1997b. Geographical variation of mitochondrial DNA between European populations of the white-clawed crayfish Austropotamobius pallipes. Freshwater Biology, 37, 493-501. 
GRANDJEAN F., GOUIN N., FRELON M., SOUTY-GROSSET C., 1998. Genetic and morphological systematic studies on the crayfish Austropotamobius pallipes (Decapoda: Astacidae). Journal of Crustacean Biology, 18 (3), 549-555.

GRANDJEAN F., HARRIS D.J., SOUTY-GROSSET C., CRANDALL K.A., 2000. Systematics of the European endangered crayfish species, Austropotamobius pallipes (Decapoda: Astacidae). Journal of Crustacean Biology, 20 (3), 522-529.

GRANDJEAN F., GOUIN N., SOUTY-GROSSET C., DIÉGUEZ-URIBEONDO J., 2001. Drastic bottlenecks in the endangered crayfish species Austropotamobius pallipes in Spain and implications for its colonization history. Heredity, 86, 431-438.

HASEGAWA M., KISHINO K., YANO T., 1985. Dating the human-age splitting by a molecular clock of mitochondrial DNA. Journal of Molecular Evolution, 22, 160-174.

HUELSENBECK J.P., CRANDALL K.A., 1997. Phylogeny estimation and hypothesis testing using maximum likelihood. Annual Review of Ecology and Systematics, 28, 437-466.

KARAMAN M.S., 1963. Studie der Astacidae (Crustacea, Decapoda). Hydrobiologia, 22, 111-132.

LARGIADÈR C.R., HERGER F., LÖRTSCHER M., SCHOLL A., 2000. Assessment of natural and artificial propagation of the white-clawed crayfish (Austropotamobius pallipes species complex) in the Alpine region with nuclear and mitochondrial markers. Molecular Ecology, 9, 25-37.

LAURENT P.J., SUSCILLON M., 1962. Les écrevisses en France. Annales de la Station Centrale d'Hydrobiologie, 9, 336-395.

LÖRTSCHER M., STUCKI T.P., CLALUNA M., SCHOLL A., 1997. Phylogeographic structure of Austropotamobius pallipes populations in Switzerland. Bull. Fr. Pêche Piscic., 347, 649-661.

MACHINO Y., 1997. New white-clawed crayfish Austropotamobius pallipes (Lereboullet, 1858) occurrences in Carinthia, Austria. Bull. Fr. Pêche Piscic., 347, 713-720.

POSADA D., CRANDALL K.A., 1998. ModelTest: testing the model of DNA substitution. Bioinformatics, 14, 817-818.

PRETZMANN G., 1987. A contribution to a historic analysis of Mediterranean freshwater decapods chorology. Investigacion Pesquera, 51, 17-25.

SAITOU N., NEI M., 1987. The neighbour-joining method: a new method for reconstructing phylogenetic trees. Molecular Biology and Evolution, 4, 406-425.

SANTUCCI F., IACONNELLI M., ANDREANI P., CIANCHI R., NASCETTI G., BULLINI L., 1997. Allozyme diversity of European freshwater crayfish of the genus Austropotamobius. Bull. Fr. Pêche Piscic., 347, 663-676.

STAROBOGATOV Y.I., 1995. Taxonomy and geographical distribution of crayfishes of Asia and East Europe (Crustacea: Decapoda: Astacidae). Arthropoda Selecta, 4, 3-25.

SOUTY-GROSSET C., GRANDJEAN F., RAIMOND R., FRELON M., DEBENEST C., BRAMARD M., 1997. Conservation genetics of the white-clawed crayfish Austropotamobius pallipes: the usefulness of the mitochondrial DNA marker. Bull. Fr. Pêche Piscic., 347, 677-692.

SOUTY-GROSSET C., GRANDJEAN F., GOUIN N., 1999. Molecular genetic contributions to conservation biology of the European native crayfish Austropotamobius pallipes. Freshwater Crayfish, 12, 371-386.

SWOFFORD D.L., 1998. PAUP* - Phylogenetic Analysis Using Parsimony ( ${ }^{*}$ and other methods), version 4. Sinauer Associates, Sunderland.

TSIGENOPOULOS C.S., BERREBI P., 2000. Molecular phylogeny of North Mediterranean Freshwater Barbs (genus Barbus: Cyprinidae) inferred from Cytochrome b Sequences: Biogeographic and systematic implications. Molecular Phylogenetics and Evolution, 14 (2), 165-179.

WILSON A.C., CANN R.L., CARR S.M., 1985. Mitochondrial DNA and two perspectives on evolutionary genetics. Biol. J. Linn. Soc., 26, 375-400. 